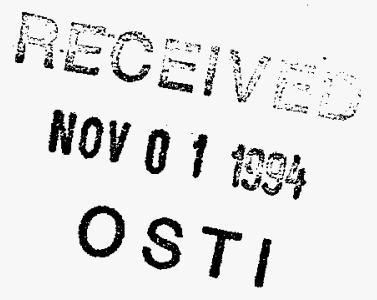

\title{
Environment, Safety, Health, and Quality Plan for the Buried Waste Integrated Demonstration Program
}

S. Walker

Published May 1994

\author{
Idaho National Engineering Laboratory \\ EG\&G Idaho, Inc. \\ Idaho Falls, Idaho 83415
}

Prepared for the

U.S. Department of Energy

Assistant Secretary for Environmental Restoration and Waste Management

Office of Technology Development

Under DOE Idaho Operations Office

Contract DE-AC07-76ID01570

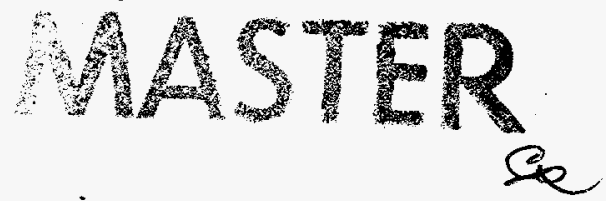




\section{DISCLAIMER}

This report was prepared as an account of work sponsored by an agency of the United States Government. Neither the United States Government nor any agency thereof, nor any of their employees, make any warranty, express or implied, or assumes any legal liability or responsibility for the accuracy, completeness, or usefulness of any information, apparatus, product, or process disclosed, or represents that its use would not infringe privately owned rights. Reference herein to any specific commercial product, process, or service by trade name, trademark, manufacturer, or otherwise does not necessarily constitute or imply its endorsement, recommendation, or favoring by the United States Government or any agency thereof. The views and opinions of authors expressed herein do not necessarily state or reflect those of the United States Government or any agency thereof. 


\section{DISCLAIMER}

Portions of this document may be illegible in electronic image products. Images are produced from the best available original document. 
Environment, Safety, Health, and Quality Plan for the Buried Waste Integrated Demonstration Program

EGG-WTD-11216

Prepared by

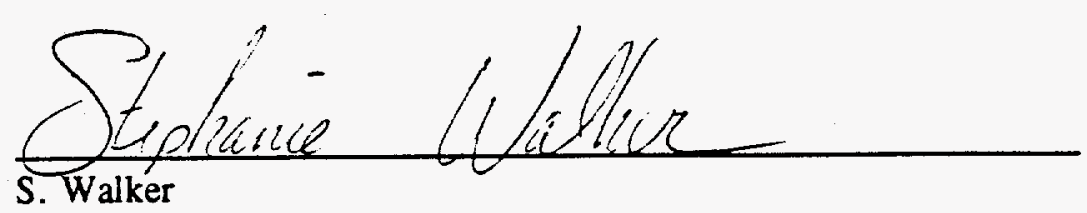

S. Walker

Senior Engineer

Reviewed by

R.W. Bomenterg

R. W. Bonnenberg

BWID Deployment Project Manager

Approved by

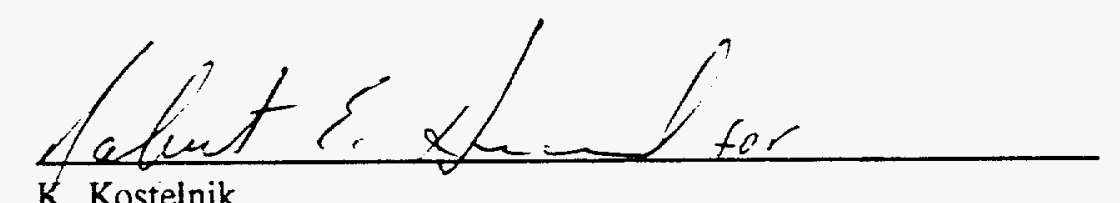

K. Kosteinik BWID Coordinator

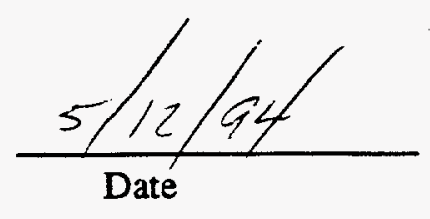

$$
5 / 13 / 94
$$

Date

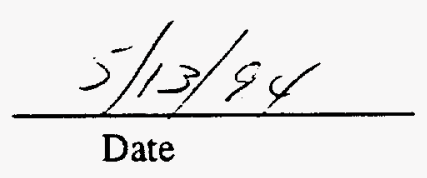




\begin{abstract}
The Buried Waste Integrated Demonstration (BWID) is a program funded by the U.S. Department of Energy Office of Technology Development. BWID supports the applied research, development, demonstration, testing, and evaluation of a suite of advanced technologies that together form a comprehensive remediation system for the effective and efficient remediation of buried waste.

This document describes the Environment, Safety, Health, and Quality requirements for conducting BWID activities at the Idaho National Engineering Laboratory. Topics discussed in this report, as they apply to BWID operations, include Federal, State of Idaho, and Environmental Protection Agency regulations, Health and Safety Plans, Quality Program Plans, Data Quality Objectives, and training and job hazard analysis. Finally, a discussion is given on CERCLA criteria and System and Performance audits as they apply to the BWID Program.
\end{abstract}




\section{SUMMARY}

The major goal in writing this report is to confirm and show BWID's commitment for ensuring that operations at the INEL and offsite are conducted in conformance with all applicable environmental regulations. As specified in this report, protocols are in place to conduct BWID operations under all environmental guidelines.

The National Environmental Policy Act of 1969 declared a national policy of greater environmental awareness by requiring a systematic, interdisciplinary review of any proposed Federal action. This review is designed to assess the environmental impacts of the action, propose and assess any aiternatives to the action, and state any irreversible and irretrievable commitments of resources should the proposed action be implemented. It also requires consultation with and comments from any Federal, state, and local agencies with jurisdiction or interest in the proposed action, as well as providing an opportunity for public input.

All BWID field demonstrations at the INEL in FY 94 will be performed at the Cold Test Pit and the Box Canyon Site. Although BWID has received approval for creation and general use of the site, each project that will demonstrate a technology at the Cold Test Pit must undergo separate NEPA review and approval. Documentation regarding these decisions will be located in the BWID program files.

Solid wastes generated from BWID operations are managed in accordance with the EG\&G Idaho Company Procedures Manual, Section 8.12. BWID projects performed at the INEL are covered by the Health and Safety Plan for the Office of Technology Development (OTD). Projects performed at the non-EG\&G Idaho facilities will be responsible for following an acceptable health and safety plan for the location where the work is performed. Hazard Communication requirements are a result of Occupational Safety and Health Administration (OSHA) regulations regarding the use of hazardous chemicals. MSDSs will be located in the administration trailer, near the Cold Test Pit. A job hazard analysis will be performed and will entail a review of the chemical, biological, and physical hazards of the operation as well as the Industrial Hygienist's (IHs) and Safety Engineer's evaluations or risk assessments of the hazards.

All work performed at the INEL must be reviewed and approved by a Facility Health and Safety Representative, as required, and documented in Safe Work Permits. All work shall be performed in compliance with all of the health and safety requirements for the BWID project as identified in both generic and project-specific training requirements to ensure the safety of project personnel has been identified. Safety walkdowns of the CTP area shall be conducted by the BWID safety engineer. Safety discrepancies and concerns shall be reported to the BWID Deployment Project Manager. Corrections will be funded and completed by BWID or by the demonstration Principal Investigator, depending on the nature of the identified problem.

Quality program plans shall be used for BWID demonstrations per DOE Order $5700.6 \mathrm{C}$, DOE-ID Order 5700.6E, and the EG\&G Idaho Quality Manual and their relevance is discussed in this report. Data Quality Objectives, qualitative and quantitative ${ }^{-+n t e m e n t s ~ t h a t ~ s p e c i f y ~ t h e ~}$ targeted quality required of data gathered during testing, will be used for BWID operations. Performance audits are conducted to quantitatively evaluate the outputs of a measurements 
system. System audits are conducted to qualitatively evaluate the operational details of a quality assurance (QA) program. These audits will be conducted internally by the BWID Deployment QA support member.

BWID has included the CERCLA criteria for evaluating the buried waste remediation technologies it is funding. These criteria are used because end products of BWID are intended for use by Environmental Restoration/Waste Management (ER/WM), who will be required to comply with CERCLA. 


\section{CONTENTS}

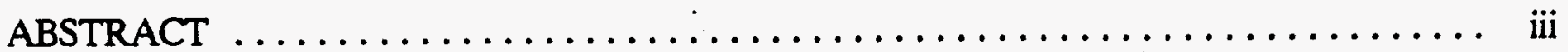

SUMMARY $\ldots \ldots \ldots \ldots \ldots \ldots \ldots \ldots \ldots \ldots \ldots \ldots \ldots \ldots \ldots \ldots \ldots \ldots \ldots \ldots \ldots \ldots, \mathrm{v}$

ACKNOWLEDGMENTS $\ldots \ldots \ldots \ldots \ldots \ldots \ldots \ldots \ldots \ldots \ldots \ldots \ldots \ldots \ldots \ldots \ldots \ldots \ldots$

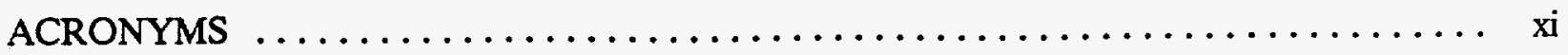

1. ENVIRONMENTAL ISSUES $\ldots \ldots \ldots \ldots \ldots \ldots \ldots \ldots \ldots \ldots \ldots \ldots \ldots$

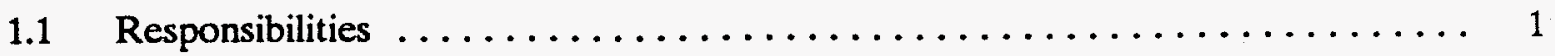

$1.2 \quad$ NEPA and Associated Regulations $\ldots \ldots \ldots \ldots \ldots \ldots \ldots \ldots \ldots \ldots \ldots \ldots$

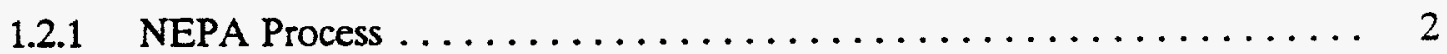

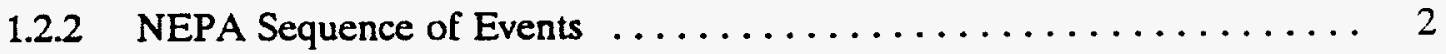

1.3 Waste Minimization and Pollution Prevention $\ldots \ldots \ldots \ldots \ldots \ldots \ldots, 4$

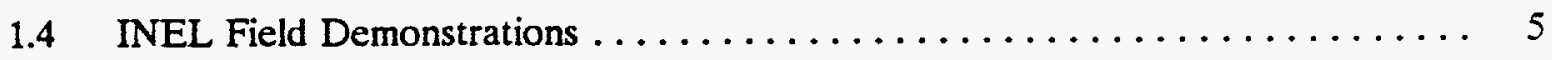

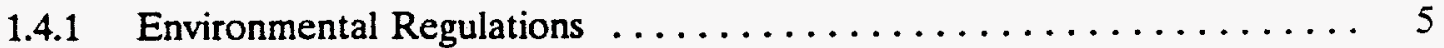

1.4.2 Waste Disposal ............................. 5

2. HEALTH AND SAFETY ISSUES $\ldots \ldots \ldots \ldots \ldots \ldots \ldots \ldots \ldots \ldots \ldots \ldots \ldots \ldots \ldots \ldots$

$2.1 \quad$ Health and Safety Plan $\ldots \ldots \ldots \ldots \ldots \ldots \ldots \ldots \ldots \ldots \ldots \ldots \ldots \ldots \ldots \ldots \ldots$

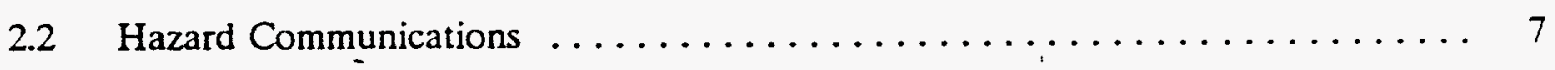

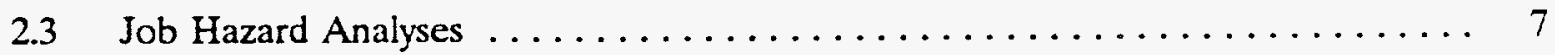

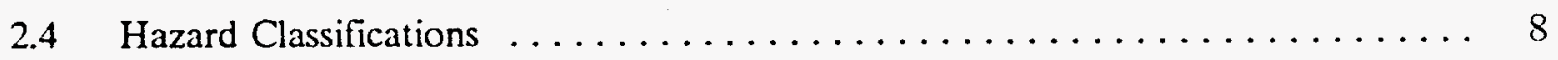

$2.5 \quad$ Training $\ldots \ldots \ldots \ldots \ldots \ldots \ldots \ldots \ldots \ldots \ldots \ldots \ldots \ldots \ldots \ldots \ldots \ldots \ldots \ldots \ldots \ldots$

2.6 Safety Reviews and Checks $\ldots \ldots \ldots \ldots \ldots \ldots \ldots \ldots \ldots \ldots \ldots \ldots$

$2.7 \quad$ Safe Work Permits $\ldots \ldots \ldots \ldots \ldots \ldots \ldots \ldots \ldots \ldots \ldots \ldots \ldots \ldots \ldots \ldots \ldots \ldots \ldots \ldots$

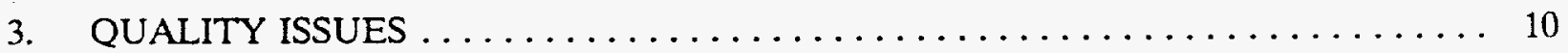

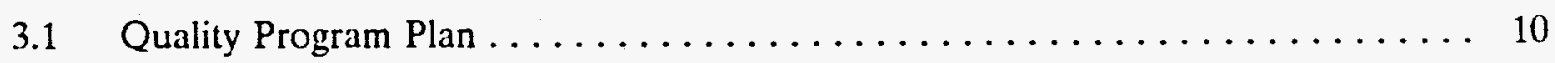

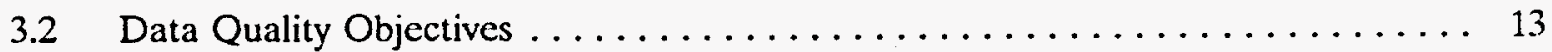


3.3 Comprehensive Environmental Response, Compensation, and Liability Act (CERCLA) Evaluation Criteria..$\ldots \ldots \ldots \ldots \ldots \ldots \ldots \ldots \ldots \ldots \ldots \ldots$

3.4 Performance and System Audits $\ldots \ldots \ldots \ldots \ldots \ldots \ldots \ldots \ldots \ldots \ldots \ldots \ldots \ldots \ldots \ldots$

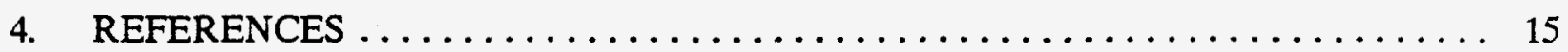




\section{ACKNOWLEDGMENTS}

The author thanks the following EG\&G Idaho personnel for contributing to this report: Lewis Rounds, Jim Graham, Rudy Bonnenberg, John Morrison, Larry Watson, and Doug Stacey. 


\section{ACRONYMS}

ALARA As Low As Reasonably Achievabie

ANSI American National Standards Institute

ARARs Applicable or Relevant and Appropriate Requirements

BLM Bureau of Land Management

CERCLA Comprehensive Environmental Response, Compensation, and Liability Act

CFA Central Facilities Area

CX Categorical Exclusion

DOPs Detailed Operating Procedures

DQOs Data Quality Objectives

EC Environmental Checklist

ER\&A Environmental Research and Application

ER/WM Environmental Restoration/Waste Management

ESG Environmental Support Group

F\&M Facilities and Maintenance

HP Health Physics

IH Industrial Hygienist

LDR Land Disposal Restriction

M\&TE Measurement and Test Equipment

NEPA National Environmental Policy Act

O\&M Operation and Maintenance

OSHA Occupational Safety and Health Administration

OTD Office of Technology Development

PPEs Personnel Protective Equipment 
PWAs Process Waste Assessments

QA Quality Assurance

QPPs Quality Program Plans

RCRA Resource Conservation and Recovery Act

SARA Superfund Amendments and Reauthorization Act of 1986

SWPPP Stormwater Pollution Prevention Plan

T\&E Threatened and Endangered

TTPs $\quad$ Technical Task Plans 


\section{Environment, Safety, Health, and Quality Plan for the Buried Waste Integrated Demonstration Program}

\section{ENVIRONMENTAL ISSUES}

\subsection{Responsibilities}

BWID and personnel involved in BWID-sponsored projects have the joint responsibility for assuring that operations at the INEL and offsite are conducted in conformance with all applicable environmental regulations. All personnel (both onsite and offsite) are expected to be guided by the EG\&G Environmental Policy in forming plans, setting objectives, and conducting their day-today activities. This policy, as stated in the EG\&G Idaho Environmental Manual (EG\&G 1993a), is as follows:

EG\&G Idaho, Inc. is committed to the environmental preservation and restoration of the INEL. As responsible stewards, we will conduct our activities in such a manner as to protect the physical environment by complying with applicable regulations. Because of our strong regard for environmental protection, we will manage and operate the INEL in a manner that gives priority to this protection.

All BWID projects are required in their Technical Task Plans (TTPs) to receive approval of documentation required by the National Environmental Policy Act (NEPA). PIs must prepare an Environmental Checklist (EC) at the beginning of the project and submit the EC to BWID or, if activities will be performed at another government facility, to the respective DOE field office or other government agency. Copies of NEPA documentation prepared at other government facilities must be supplied to the BWID ESH\&Q representative Lewis Rounds [(208) 526-0063].

The BWID ESH\&Q representative has the responsibility to submit the EC to the EG\&G Idaho Environmental Support Group (ESG). ESG assists BWID with conforming to requirements of the National Environmental Policy Act (NEPA) and all other applicable environmental regulations. ESG has received authority from DOE-ID to be the point of contact for EG\&G Idaho NEPA actions. Jim Graham has been designated as the ESG interface for BWID projects/actions. He is responsible for ensuring timely NEPA review and recommendation of the appropriate NEPA documentation for proposed actions as requested by BWID. Requests for NEPA review are coordinated by the BWID ESH\&Q representative, who tracks the status of all documentation and ensures that all projects prepare NEPA documentation and that approval by the DOE responsible supervisory official is received prior to project initiation.

Each PI is responsible for minimizing the generation of both hazardous and nonhazardous wastes. BWID will assist with recycling efforts as mentioned in Section 1.3.

\subsection{NEPA and Associated Regulations}

The National Environmental Policy Act of 1969 declared a national policy of greater environmental awareness by requiring a systematic, interdisciplinary review of any proposed 
Federal action. The review is designed to assess the environmental impacts of the action; propose and assess alternatives to the action, if any, and state any irreversible and irretrievable commitments of resources involved in the proposed action should it be implemented. It also required consultation with and comments from any Federal, state, and local agencies with jurisdiction or interest in the proposed action, as well as providing an opportunity for public input.

Compliance with NEPA and its documentation requirements is mandatory for proposed Federal actions involving new construction and/or modifications, and upgrades or changes to existing facilities, projects, programs, and activities. Federal actions include activities that are performed by Federal employees, take place on Federal property, and/or are Federally funded. Physical activities such as site preparation, material purchases, irreversible commitment of resources, or any other action that tends to preclude implementation of reasonable alternatives cannot proceed until DOE written approval of NEPA documentation has been received.

\subsubsection{NEPA Process}

In addition to determining the type of NEPA documentation required for the proposed action, the NEPA review process includes review for the applicability of the following:

- The Clean Air Act and State of Idaho implementing regulations that apply to any construction, modification, or operation of equipment that emits pollutants into the atmosphere.

- The Resource Conservation and Recovery Act (RCRA), which applies to management of solid and hazardous wastes.

- The Safe Drinking Water Act, which applies to any industrial or domestic waste water treatment or disposal action.

- The Clean Water Act, which protects threatened or endangered organisms.

- The American Indian Religious Freedom Act.

- DOE Orders that regulate radiation exposures to personnel to as low as reasonably achievable (ALARA) levels.

- Other laws and regulations (e.g., state laws) applicable to the proposed action.

The ESG and the BWID ESH\&Q representative will assist the PI with resolving any condition that arises during this review, such as applying for an air permit.

\subsubsection{NEPA Sequence of Events}

The process for NEPA documentation approval within the BWID program is summarized below. This summary discusses primarily the projects whose NEPA is the responsibility of EG\&G Idaho. Projects that are performed at other government facilities are the responsibility of the company performing the task and PIs will submit ECs and obtain NEPA approval through their 
respective agency or field office. Copies of ECs and approved NEPA shall be supplied to BWID within 10 working days of preparation or approval. Any problems with receiving approval should be discussed with the BWID ESH\&Q contact as soon as possible.

1. The project PI (or PM) prepares an EC at the beginning of the project and submits the checklist to BWID through the BWID ESH\&Q representative. All projects must prepare ECs, including those involving only office work. Sample ECs may be obtained from Lewis Rounds or Jim Graham.

2. The BWID ESH\&Q representative submits the EC to ESG for review and a recommendation of the appropriate level of NEPA documentation. Typically, an EC review and generation of a Categorical Exclusion (CX) by ESG takes 15 working days.

3. The BWID ESH\&Q representative tracks the progress of NEPA documentation to ensure all BWID projects file for DOE approval.

4. When ESG receives the EC, an official file is established by issuing a tracking number to the project.

5. ESG performs a review of the EC per the following:

a. Determine if the EC meets minimum requirements (i.e., is the form the latest revision of the EC? Are all data fields addressed? Are contacts identified? Is the project description, purpose, and need clearly stated?).

b. Determine if the EC is internally consistent (i.e., does the environmental concerns section match a project of this type? If waste disposal is part of the action, is the solid waste question answered "yes").

c. Initiate RCRA air and water (or other environmental regulations) review and determine impacts to any environmentally sensitive areas (e.g., floodplains/wetlands, threatened or endangered species, cultural resources) and assess impacts in the NEPA documentation.

d. Determine if the environmental concerns are adequately addressed and review the proposed action for DOE "sensitivities" (i.e., is the proposed action unusual or in an area that has required special review and consideration in the past?).

e. The ESG reviewer typically requires discussions with BWID, the PI, and/or the PM during this phase of the NEPA process in order to document details of the proposed action and adequately assess potertial impacts.

6. ESG makes a NEPA documentation recommendation, prepares a CX if appropriate, checks the Category Evaluation Criteria in Section D for accuracy and signs the EC in Section E. 
7. PI/PM review for accuracy is obtained, the project data are recorded in the official project file, and the PI/PM is formally notified of the NEPA recommendation via the BWID interface in ESG.

8. Upon receipt of the NEPA document package from ESG, the PI/PM concurs with or advises ESG that factual errors have been made and ensures correction.

NOTE: If ESG determines at this point that the proposed action is included in a previously approved NEPA document, no further NEPA review or documentation will be required.

9. If applicable, the BWID ESH\&Q representative transmits the ESG-approved NEPA package to the appropriate DOE-ID Division Director for entry into the DOE-ID NEPA documentation review process, and provides a copy of the transmittal correspondence to ESG. The CX/EC package then requires review and approval by the DOE-ID approval chain, which requires approximately 20-60 working days.

10. The PI/PM ensures that the document is approved by DOE-ID before proceeding with the action, ensures compliance with any conditions as stated in the NEPA document package, and provides information on new proposed actions and update information on ongoing actions to ESG.

\subsection{Waste Minimization and Pollution Prevention}

The mission of the BWID program is to assist in environmental remediation, primarily through testing and evaluation of advanced technologies for waste characterization, retrieval, treatment, and containment. Little, if any, new hazardous waste is generated as a function of testing and demonstrating remediation technologies. At this time, no process has been identified in the 1994 (or out-year) demonstration and test programs that would generate new hazardous. radioactive, mixed, or land disposal restriction (LDR) waste.

The BWID program is represented in the Environmental Research and Application's (ER\&A) 1994 Waste Minimization Plan, Subsection 2.10, "Waste Technology Development." Process Waste Assessments (PWAs), required by the plan for tracking waste minimization efforts, are not required for non-routine activities, and are not required for municipal waste, sanitary waste, or office trash. It is expected that some construction debris, such as broken glass, wood scraps, packaging materials, cement, and rubble, will be left at the Cold Test Pit when the tests are completed. At BWID's request, the CFA Landlord and program support Facilities and Maintenance (F\&M) services will remove this industrial waste and dispose of it properly at the CFA landfill. Scrap metal will be moved to CFA property control for recycling.

Simulated waste retrieved during excavation demonstrations at the Cold Test Pit will be reused to the extent it is feasible. When possible, the waste will either be reused as a source for treatment technologies funded by BWID, reburied in the Cold Test Pit for future retrieval demonstrations, or stockpiled in containers at the Cold Test Pit for future pit construction. Any remaining simulated waste from retrier demonstrations will be disposed of in the CFA landfill. 


\subsection{INEL Field Demonstrations}

\subsubsection{Environmental Regulations}

All field demonstrations at the INEL in FY 94 will be performed at the Cold Test Pit and the Box Canyon Site. Although BWID has received approval for creation and general use of the site, each project that will demonstrate a technology at the Cold Test Pit must undergo separate NEPA review and approval. The Cold Test Pit has received archaeological clearances, threatened and endangered (T\&E) species clearances, and approval of a Stormwater Pollution Prevention Plan (SWPPP), as required. These documents are located in the BWID program files.

The Box Canyon site is located on Bureau of Land Management (BLM) property. Therefore, the BLM is responsible for ensuring NEPA requirements have been met. NEPA documentation and T\&E surveys have been completed by the BLM. Archeological surveys were completed in the spring of 1994.

\subsubsection{Waste Disposal}

Procedures for disposal of solid wastes are contained in the EG\&G Idaho Company Procedures Manual, Section 8.12, "Solid Sanitary Waste Segregation and Recycling Procedures for using the INEL Landfill," (EG\&G 1993b). BWID will have three dumpsters placed at the CTP to receive metal, wood, and other refuse (e.g., office paper).

Hazardous waste generation from BWID tests is discouraged, but controlled materials, such as hydraulic fluids, have been used in the past and their use is anticipated again in the future. The RWMC Spill Prevention Plan will be used at the CTP. The Monolithic Confinement Project will define a Spill Plan for the Box Canyon Site. Secondary wastes from field tests are the responsibility of each technology. The BWID Deployment Team will support the removal and ultimate disposal of secondary waste streams if requested by the PIs. 


\section{HEALTH AND SAFETY ISSUES}

\subsection{Health and Safety Plan}

BWID projects performed at the INEL shall comply with NIOSH/OSHA/USCG/EPA (1985), Occupational Safety and Health Guidance Manual for Hazardous Waste Site Activities; the EG\&G Safety Manual (EG\&G 1994a); the EG\&G Radiological Controls Manual (EG\&G 1994b); and EPA Standard Operating Safety Guides (EPA 1984). Projects performed at the INEL are covered by the Health and Safety Plan for the Office of Technology Development (EG\&G 1994c). Projects performed at non-EG\&G Idaho facilities will be responsible for following an acceptable health and safety plan for the location where the work is performed. Vendors who will be working at the INEL are required to produce safety plans for the work they will be performing. Approval of both the PI and the BWID safety engineer are required before the vendor arrives at the INEL.

All technology development projects sponsored by BWID shall use the following checklist to identify Health and Safety compliance issues. If any item on this check list is a "yes" then the performer may be required to generate additional Detailed Operating Procedures (DOPs). This will be on a case-by-case basis to meet the guidance and requirements as directed by BWID management for the specific identified issues. The DOP will be attached as an "Addendum" to the ER Health and Safery Plan (EG\&G 1991).

1. Are there any specialized training requirements involving radioactive or hazardous material that were not called out in your Demonstration Test Plan?

2. Do any of the activities of your demonstration require the use of any hazardous material or involve the performance of hazardous activities requiring mandatory use of specialized protective procedures? For example, fueling up a portable generator is a "no," but the use of a controlled radioactive source is a "yes."

3. Do any of the activities of your demonstration require the mandatory use of specialized protective clothing or equipment beyond hard hats, safety shoes, safety glasses, or ear plugs? For example, projects requiring the use of respirators or anti-C's for personal protection would be a "yes."

4. Do any of the activities of your demonstration require an exclusion zone because of excessive hazards, especially contamination? For example a safety rope around a relatively shallow excavation would be a "no," but a radioactive or hazardous exclusion barrier would be a "yes." However, a simulated exclusion zone that is for the purpose of simulating reality during a "cold" demonstration would be a "no."

5. Do any of the activities of your demonstration require a environmental remediation or decontamination activity to remove radioactive or hazardous contamination that was a result of your demonstration? 
6. Do any of the activities of your demonstration require specialized environmental monitoring for hazardous or radioactive contamination, or for excessive hazards of fire, explosion, high heat, confined space, or high noise? Will any activities be performed in an area defined as a "confined space?"

7. Do any of the activities of your demonstration require specialized emergency or containment equipment for fire, explosion, or contamination release (hazardous or radioactive?) For example, fire extinguisher presence would be a "no," but a stand-by fire engine or the required presence of Health Physicists (HPs) with a hazardous/radioactive spill control kit would be a "yes."

\subsection{Hazard Communications}

Hazard Communication requirements are a result of Occupational Safety and Health Administration (OSHA) regulations regarding the use of hazardous chemicals. Issues that must be addressed include availability of MSDSs, a hazardous agent inventory, proper labeling, and appropriate training for personnel.

At the Cold Test Pit, all MSDSs will be located in the administration trailer. All PIs performing tests at the Cold Test Pit shall ensure that copies of the MSDSs of any chemicals they will be using are included in the MSDS binder. Copies of MSDSs for chemicals used at the Box Canyon site shall be located in an easily accessible location to be determined by project members.

All chemicals to be used at the INEL and the amounts to be used shall be listed and provided to the ESH\&Q representative, who will ensure compliance with the Superfund Amendments and Reauthorization Act of 1986 (SARA) reporting regulations. Proper labeling and training for use of the chemical will be the responsibility of the PI.

All other projects shall follow the existing procedures of the facilities in which work is performed.

\subsection{Job Hazard Analyses}

A job hazard analysis is required for each project performed at the INEL. The analysis entails a review of the chemical, biological, and physical hazards of the operation as well as the Industrial Hygienist's (IHs) and Safety Engineer's evaluations or risk assessments of the hazards. Based on this analysis, the following issues may need to be addressed by the PI and the IH or Safety Engineer:

- Confined Spaces-A certified IH or Safety Engineer will classify, inspect, and review all potential confined spaces.

- Hearing Conservation-Noise levels that exceed 85 decibels for $8 \mathrm{hr} /$ day duration, as measured i a sound level meter conforming to ANSI specification, 51.4 (1971) Type 52A, and set to use the A-weighted network with slow meter response. Work will 
be restricted to $1 \mathrm{hr}$ per day if the noise level reaches 100 decibels. All test operations will shut down if the noise level should reach 115 decibels.

- Carcinogen Control-Will be implemented if DOE-specified carcinogens must be used by a project. The BWID IH will monitor the use of any carcinogens.

- Industrial Hygiene Monitoring-The BWID IH will monitor the presence of chemicals and other hazardous agents at the site, if required. An assessment regarding the frequency and type of monitoring will be addressed in the job hazard analysis.

- General working conditions.

- Construction safety.

- Forklift operation.

- Gantry crane operation.

- $\quad$ Personnel protective equipment (PPE).

- $\quad$ High-pressure system training.

- Emergency procedures.

- Trenching.

- Operation of earth moving equipment.

\subsection{Hazard Classifications}

Hazard classification evaluations are to be performed for all BWID-sponsored projects before they go to the field for demonstration. Hazard classification evaluations are the responsibility of the PIs.

\subsection{Training}

BWID projects performed at the INEL shall comply with the minimum training requirements as outlined in Training Requirements and Responsibilities for the Buried Waste Integrated Demonstration at the Radioactive Waste Complex (EG\&G 1992a).

\subsection{Safety Reviews and Checks}

The BWID safety engineer shall conduct a safety walkdown of the CTP area weekly when field der...nstrations are being performed. Safety discrepancies and concerns shall be reported to the BWID Deployment PM. Corrections will be funded and completed by BWID or by the demonstration PI, depending on the nature of the identified problem. 
BWID and subcontractor personnel are responsible for complying with the applicable sections of the EG\&G Idaho, Inc., Safety Manual (EG\&G 1994a), the EG\&G Idaho Industrial Hygiene Manual (EG\&G 1993c), the RWMC Operational Safety Requirements Safety Analysis Report (EG\&G 1988), the EG\&G Idaho Conduct of Operations Manual (EG\&G 1993d), and the Environmental Restoration Program Preparation of Task-Specific Health and Safety Plans (EG\&G 1992b). If required, safety-related training is available from centralized safety training at the Central Facilities Area (CFA).

\subsection{Safe Work Permits}

All work performed at the INEL must be reviewed and approved by a Facility Health and Safety Representative, and documented in Safe Work Permits as determined by the safety representative. All work will be performed in compliance with all of the health and safety requirements for the BWID project as identified in the BWID PMP, and as required by this ESH\&Q plan for BWID. 


\section{QUALITY ISSUES}

This section provides information to assist PIs in providing quality projects and quality data for the BWID program. The sub-elements of this section are Quality Program Plans (QPPs), Data Quality Objectives (DQOs), and Comprehensive Environmental Response, Compensation, and Liability Act (CERCLA).

\subsection{Quality Program Plan}

DOE Order 5700.6C, DOE-ID Order 5700.6E, and the EG\&G Idaho Quality Manual (EG\&G 1994d) require that all projects are performed using an issued and established quality program plan. The basis for DOE Order 5700.6C, DOE-ID Order 5700.6E, and the EG\&G Idaho Quality Manual is the American Society of Mechanical Engineers, Quality Assurance Program Requirements for Nuclear Facilities, ASME/ANSI NQA-1 (ASME 1991). NQA-1 is divided into two sections, basic requirements and supplements. In the basic requirements section, the elements that make up a good quality program for any program/project are defined. The supplemental section is used primarily for nuclear facilities or nuclear reactors. The basic requirements in NQA-1 are approximately the same as those found in the Code of Federal Regulations 10 CFR 50 and the American National Standards Institute (ANSI) 45208, both of which address quality programs. For BWID, DOE has chosen NQA-1 for the basic quality assurance program.

The purpose of a QPP is to identify how the project will meet its objectives in areas such as design, procurement, fabrication, testing, verification of processes, and documentation of all the above. In other words, "did the project get what it paid for and in the form required?" All DOE-sponsored projects must be covered by a QPP.

Projects funded by BWID have three choices for QPPs:

1. Use QPP-044 rev. E, (Quality Program Plan for the Engineering Research and Applications Department, with Office of Waste Technology Development supplement) dated August 2, 1993, for projects that were started after December 1992. This QPP contains a supplement for the Waste Technology Development Program and will satisfy all quality requirements.

2. Use QPP-337, (Quality Program Plan for the Waste Technology Development Department) dated November 12,1991. This QPP was written for use by the WTD Department and is still acceptable for projects that were initiated in FY 92 or 93. However, QPP-044 is recommended because it is easier to use and more current.

3. Write a QPP per the requirements identified in EG\&G Idaho Quality Manual QP-2 (EG\&G 1994d) or NQA-1.

QPP-044 and -337 (mentioned above) were written to cover almost y project. Project personnel should remember that each element of a QPP should be applied using a graded 
approach. Elements of the chosen QPP should be implemented with the rigor that is appropriate for the project needs, and what is required to meet the project objectives.

To assist the project members in determining what portions of their QPP should be carefully reviewed and understood, the following descriptions of the elements of all QPPs are given below.

QP-1 Organization-The assignment of responsibilities, such as who is responsible for verification that quality has been achieved.

QP-2 Quality Program-What level of quality is required and how will it be accomplished. This is what drives a QPP.

QP-3 Design Control-How designs are defined, controlled, and verified.

QP-4 Procurement Document Control-What procurement documents are required, what information is required on those documents and how changes are implemented.

QP-5 Instructions, Procedures, and Drawings-Do operating instructions, procedures and drawings receive the right reviews and do they contain the necessary quantitative or qualitative acceptance criteria?

QP-6 Document Control-Documents that specify quality requirements or prescribe activities affecting quality shall be prepared, issued, and changed in a controlled manner.

QP-7 Control of Purchased Items and Services-The quality of purchased materials. equipment and services shall be controlled to ensure conformance to procurement document requirements.

QP-8 Identification and control of Items-To ensure that only correct and accepted items are used or installed.

QP-9 Control of Processes-This refers to special processes that control or verify quality, such as welding, brazing, heat treating, and nondestructive examinations.

QP-10 Inspection-Inspections required to verify conformance of items and activities to specified requirements shall be performed by personnel independent from those who performed or directly supervised the items or activity being inspected. This also includes inspection plans when needed.

QP-11 Test Control-Tests required to verify conformance of an item or computer program to specified requirements and to demonstrate that items will perform satisfactorily in service shall be planned and executed. 
QP-12 Control of Measuring and Test Equipment-Measurement standards and measurement and test equipment (M\&TE) used in fulfilling contractual requirements and for activities affecting quality shall be controlled and calibrated at specified intervals and adjusted to maintain required accuracy.

QP-13 Handling, Storage, and Shipping-Measures shall be established to control the handling, packaging, cleaning, preservation, storage, transporting and shipping of material and equipment to prevent damage, loss, or deterioration.

QP-14 Inspection, Test, and Operating Status-The status of items and operating facilities shall be identified and controlled to ensure that items that have not passed required inspections and tests are not inadvertently installed, used or operated.

QP-15 Control of Nonconforming Items-Items that do not conform to requirements shall be controlled to prevent inadvertent use or installation.

QP-16 Corrective Action-The identification, cause, and corrective actions to prevent recurrence shall be determined and documented for significant conditions adverse to quality.

QP-17 Quality Records-Records shall be specified, prepared, reviewed, approved, and maintained to accurately reflect completed work and to furnish objective evidence of quality.

QP-18 Quality Audits-A system of planned and scheduled quality audits conducted to verify compliance with all aspects of the EG\&G Idaho Quality Manual. These audits will be conducted internally by the BWID Deployment QA support member.

QP-19 Readiness Review-Prior to performance, the status or prerequisites of the specified functions shall be validated by an independent review.

QP-20 Quality Improvement-Process established and implemented to detect and prevent quality problems and to ensure quality improvement.

QP-21 Computer Software Configuration Management-To establish the policy, requirements, and responsibilities for the control of computer software purchased for direct use, purchased and modified, or developed by EG\&G Idaho personnel.

Using a graded approach, the QPP should not be a cost and schedule problem, but should help ensure that project costs and schedule are met along with providing a quality product that meets the customers expectations and requirements. If there are any questions, contact the BWID Quality Engineer, Lewis Rounds [(208) 526-0063] or other qualified Quality Prolessional. 


\subsection{Data Quality Objectives}

DQOs are both qualitative and quantitative statements that specify the targeted quality required of data gathered during testing. Indicators of DQOs include precision, accuracy, representativeness, completeness, and comparability. The DQOs should be identified as early as possible. DQOs are an important part of project planning, writing procedures, and preparing test plans. In addition, established DQOs define the importance of the various sets of data, enabling decisions to be made on equipment, materials, operating procedures, cost, and schedules in a way that will best support the project.

There are several processes that can be used to determine DQOs for each project. EPA report QAMS 005/80 defines one method, but is directed primarily toward sampling data. A draft document that also provides a template for identifying project objectives and requirements has been prepared within EG\&G. Although still a draft, the document is very helpful in determining a project's DQOs. This draft document may be obtained through the BWID administrative assistant, Judy Mitte [(208) 526-0415], if needed.

The purpose of defining DQOs is to identify what data are critical, important, desirable, or not of much importance to the project. The number of categories and what data fit each category are dependent on the PI. Knowing how important each set of data is, both before and during testing, the PI can then apply the DQO indicators to each. With this information at hand, any decisions on necessary or suggested changes both before and during testing can be made with positive (or minimal) effects on the final data collected during testing. DQOs are also helpful if the project budget increases or decreases. DQOs help identify areas where increased funding will be most useful or cuts can be made with minimal effects.

A well-delined set of DQOs is an asset to a project and should be established very early. If you need help defining DQOs or have any questions, contact the BWID Quality Engineer, Lewis Rounds [(208) 526-(0)63] or other qualified Quality Professional.

\subsection{Comprehensive Environmental Response, Compensation, and Liability Act (CERCLA) Evaluation Criteria}

BWID has included the CERCLA criteria for evaluating the buried waste remediation technologies it is funding. These criteria are used because end products of BWID are intended for use by Environmental Restoration/Waste Management (ER/WM), who will be required to comply with CERCLA. The nine CERCLA criteria to be considered are as follows:

1. Overall Protection of Human Health and the Environment-This category is for analyzing whether the technology can adequately protect human health and the environment, in both the short-and long-term, from unacceptable risks.

2. Compliance with Applicable or Relevant and Appropriate Requirements (ARARs)-This category is for analyzing whet.ser the technology can comply with applicable or relevant and appropriate requirements under Federal environmental laws 
and state environmental or facility siting laws, or can provide grounds for invoking a waiver.

3. Long-Term Effectiveness and Permanence-This category is for evaluating the longterm effectiveness and permanence the technology affords, along with the degree of certainty that the technology will prove successful. Included should be an analysis of the magnitude of residual risk and the reliability and adequacy of controls.

4. Reduction of Toxicity, Mobility, and Volume Through Treatment-This category is for determining the degree to which the technology employs recycling methods or treatments that reduce the toxicity, mobility, or volume of a waste, including how treatment is used to address the principal threats posed by the site.

5. Short-Term Effectiveness-This category is for evaluating the short-term impacts of technologies, including protection of the community and workers during remedial actions, impacts on the environment, and time until remedial action objectives are achieved.

6. Implementability-This category is for identifying the ease or difficulty of implementing the technology.

7. Cost-This category is for identifying capital costs (both direct and indirect), annual operation and maintenance (O\&M) costs, and net present value of capital and O\&M costs.

8. State Acceptance-This category is for assessing State concerns and may not be completed until comments on the RI/FS are received. The category should, however, be discussed to the extent possible.

9. Community Acceptance-This category includes determining which components of the technology that persons in the community support, have reservations about, or oppose.

Additional information for each criterion can be found in EPA-540/G-89/004, Chapter 6 or Federal Register/Vol. 55, No. 46/ Thursday, March 8, 1990/ Rules and Regulations pages 8849 and 8850 .

\subsection{Performance and System Audits}

Performance audits are conducted to quantitatively evaluate the outputs of a measurements system. System audits are conducted to qualitatively evaluate the operational details of a quality assurance (QA) program. These audits will be conducted internally by the BWID Deployment QA support member.

A system audit to verify that the instrur 'nt(s) are operating within expected parameters will be done before and after the INEL demonstration by the respective operations personnel. This information will be documented in the PI's logbook. 


\section{REFERENCES}

American Society of Mechanical Engineers (ASME), 1991, Quality Assurance Program Requirements for Nuclear Facilities, ASME/ANSI NQA-1.

EG\&G Idaho, Inc. (EG\&G), 1988, RWMC Operational Safety Requirements Safety Analysis Report.

EG\&G, 1991, Health and Safety Plan for the Buried Waste Program.

EG\&G, 1992a, Training Requirements and Responsibilities for the Buried Waste Integrated Demonstration at the Radioactive Waste Management Complex.

EG\&G, 1992b, Environmental Restoration Program Model for Preparation of Task-Specific Health and Safety Plans.

EG\&G, 1993a, Environmental Manual.

EG\&G, 1993b, Company Procedures Manual.

EG\&G, 1993c, Industrial Hygiene Manual.

EG\&G, 1993d, Conduct of Operations Manual.

EG\&G, 1994a, Safety Manual.

EG\&G, 1994b, Radiological Controls Manual.

EG\&G, 1994c, Health and Safety Plan for the Office of Technology Development, EGG-WM-8771.

EG\&G, 1994d, Quality Manual.

Environmental Protection Agency (EPA), 1984, Standard Operating Safety Guides.

ER\&A, 1994 Waste Minimization Plan.

NIOSH/OSHAJUSCG/EPA, 1985, Occupational Safety and Health Guidance Manual for Hazardous Waste Site Activities. 